九州大学学術情報リポジトリ

Kyushu University Institutional Repository

\title{
Banana Flowers (Musa sp.: Musaceae): an Essential Source of Nectar for Honeybee During the Dearth Period in Egypt
}

SHAWER, B. Mohamed

Department of Economic Entomology, Faculty of Agriculture, Kafrelsheikh University

RAKHA, M. Osama

Department of Economic Entomology, Faculty of Agriculture, Kafrelsheikh University

ELNABAWY, M. Elsaid

Department of Economic Entomology, Faculty of Agriculture, Kafrelsheikh University

ELASHMAWY, A. Amr

Department of Economic Entomology, Faculty of Agriculture, Kafrelsheikh University

他

https://doi.org/10.5109/2232281

出版情報：九州大学大学院農学研究院紀要. 64 (1)，pp.79-85，2019-02-28. Faculty of Agriculture， Kyushu University

バージョン :

権利関係 : 


\title{
Banana Flowers (Musa sp.: Musaceae): an Essential Source of Nectar for Honeybee During the Dearth Period in Egypt
}

\author{
Mohamed B. SHAWER ${ }^{1}$, Osama M. RAKHA ${ }^{1}$, Elsaid M. ELNABAWY ${ }^{1}$, \\ Amr A. ELASHMAWY ${ }^{1}$ and Takatoshi UENO*
}

\author{
Laboratory of Insect Natural Enemies, Division of Biological Control, \\ Department of Applied Genetics and Pest Management, Faculty of Agriculture, Kyushu University, Fukuoka 819-0395, Japan \\ (Received October 31, 2018 and accepted November 12, 2018)
}

\begin{abstract}
A nectar dearth is a period when nectar producing flowers are scarce, and the dearth can be devastating for honeybee colonies. Provision or presence of alternative flowering plants is thus crucial to stable beekeeping. The present study was carried out at two different locations in Egypt to evaluate the importance of banana flowers as a nectar source during the dearth period (August-October) for honeybees. The investigation on nectar production and sugar content estimated that banana flowers produced a large amount of nectar with a relatively high sugar concentaration and that one feddan of banana plantation during 2016 and 2017 seasons produced 29.2 and $31.5 \mathrm{~kg}$ nectar, which contained 4.54 and $5.21 \mathrm{~kg}$ sugar. Thus, expected honey yields were 5.67 and $6.51 \mathrm{~kg}$ honey/feddan in 2016 and 2017, respectively. Field observations demonstrated that the honeybee Apis mellifera carnica frequently visited banana flowers, in particular, in the morning time and that nectar in uncovered banana flowers decreased in response to honeybee vists while nectar volume in covered flowers remained unchanged. The honeybee colonies in banana farms showed much higher flight activity (foraging and pollen collection) and productivity (stored pollen, brood rearing, bee population, queen rearing, royal jelly production and honey production) than those in control localities. We conclude that moving the apiaries to banana plantations during the dearth period can conserve the strength of honeybee colonies allowing good overwintering, and improve honey yield by $2.69 \pm 0.1 \mathrm{~kg} / \mathrm{col}-$ ony.
\end{abstract}

Key words: Horitculture, apiculture, blooming time, Apis mellifera carnica, nectar secretion

\section{INTRODUCTION}

Mutualistic relationships between flowering plants and honeybees are well known but the relationships are variable depending on plant species and flowering period, and can differ from one geographical region to another. Flowers or nectar sources are not unlimitedly available, and blooming plants should be restricted in time and space. In general, nectar sources are abundant in spring when many plant species bloom but, in summer, a shortage of nectar producing flowers may occur, in particular, in areas where low rainfall is common in that period. The length and severity of a summer nectar dearth may depend on year and place. Such dearth period can be devastating for honeybee colonies because it is also the season when colony population is high and honeybees are highly active.

Atwal (2000) has stated that the dearth period means 'no honey flow period'; also, the period when honeyees collect a relatively small amount nectar is defined as 'minor honey flow period' while the period when honeybees can collect large amount of nectar from particular plant species as 'major honey flow period'. When the floral dearth is severe, honey flow is very weak or none, and honeybee colonies can exhaust honey stocks in the hive, which may be devastating for the colonies. Also, if honeybees can not recover the honey stocks after the

${ }^{1}$ Department of Economic Entomology, Faculty of Agriculture, Kafrelsheikh University, Elgeish Street, Kafrelsheikh 33516, Egypt

* Corresponding author (E-mail: ueno@grt.kyushu-u.ac.jp) dearth period before winter, the colonies are likely to be weakened during the overwintering period.

Practices to cope with the dearth period are thus important to keep honeybee colonies healthy. A practice widely used by beekeepers is to feed sugar syrup and pollen substitutes to bee colonies when the dearth is severe or honey stores are low (Eisikowitch and Masad, 1980; Mohanna, 1989). Alternatively, it would be a good idea to move bee colonies to other areas where flowering plants or sources of nectar are reasonably available so that honey flow can be improved; this approach also can reduce the cost of artificial feeding and allow to maintain the strength of bee colonies (Taha and Bayoumi, 2006; Taha et al., 2006). Such alternative flowering plants are not necessarily to be wild plant species; instead, plants used for agricultural or ornamental purposes may be useful as an alternative nectar source for honeybees. In the present study, we focus on an alternative flowering plant in Egypt.

In Egypt, there are two distinct seasons; a mild winter from November to April and a hot summer from May to October. The period between the end of cotton flowering in September until the beginning of faba bean flowering in December is considered the floral dearth period in many regions, such as Alexandria (Mohanna, 1989), Dokki (Abo-Lila and Ghoneimy, 1998), El-Beheira (Sharaf, 1996), and Kafr El-Sheikh (Shawer, 1987). Therefore, we have to search candidate plants that should be in full bloom during that period.

There are several candidate plants considered as a secondary or alternative source of nectar and/or pollen during the dearth period in Egypt (Shawer, 1987). For 
example, the Brazilian pepper tree, Schinus terebinthifolius L., grown in Alexandria region is known to be a beneficial source of both nectar and pollen from midSeptember to mid-October (Mohanna, 1989). In Motobes District, Kafr El-Sheikh, loofah, Luffa aegyptiaca Mill., is a good source of nectar between June and November (Taha et al., 2006). Coconut palm Cocos nucifera may be a good pollen source for honeybees because, in India, coconut palm constitutes 91-100 \% of the total monthly pollen collection by Apis cerana colonies during the period from April to October, when other pollen sources are few (Suryanarayana et al., 1990). Ornamental plants such as Abelia grandiflora and Antignon leptopus can also be nectar sources (Abrol, 2004).

Banana is one of the major fruit crops in the world; around 113.3 million tonnes of banana were produced in 2016 from 5.5 million hectares in nearly 130 countries. Banana is an essential crop in Africa (Karamura et al., 2008), which contributes about $18.5 \%$ of the total banana production all over the world. In Egypt, banana is an important fruit crop; the total cultivated area is estimated as 65,790 feddans and the annual production in the country is about 1,34 million tonnes (FAO, 2016). Banana is one of the ancient domestic crops in the Arabian region (Al-Busaidi, 2013), and total production is about $3 \%$ of the world banana production.

Musaceae, including the genus Musa, to which banana belongs, blooms "nectar rich" flowers. Flowers of Musa are large in size and visually conspicuous, and are often pollinated primarily by birds or bats (Itino et al., 1991; Endress, 1994; Liu et al., 2002). However, various other visitors are recorded from flowers of banana or Musa spp., and, among Insecta, Apidae is a group of bees that often visit banana flowers (e.g., Itino et al., 1991; Free, 1993; Rutikanga et al., 2016). In Egypt, workers of the honeybee Apis mellifera carnica are often found visiting banana flowers. Given that banana is widely cultivated in the country and that banana blooms during the dearth period, banana may be a good candidate of alternative flowers for honeybees in the dearth period.

Accordingly in the present study, we assessed the importance of banana flowers as a source of nectar for honeybees during the dearth period. For this purpose, we evaluated the role of banana flowers on the activity and productivity of honeybee colonies during the dearth period in Egypt. Basing on the results, we discuss the usefulness of banana flowers for beekeeping.

\section{MATERIALS AND METHODS}

\section{Study site and experimental design}

The study was carried out during two successive seasons, 2016 and 2017, throughout the main blooming time of banana between early August and mid-October to evaluate whether banana flowers was a suitable source of nectar/pollen for honeybees during the dearth period in Egypt. Apis mellifera carnica was a study honeybee in our study. In all, 18 same-strength colonies with 10,000 individuals each, which were headed by open-mated sister queens, were prepared for the following experiment. Colonies were then divided into two equal groups; one group was placed in Qulin region, Kafr El-Sheikh Govenorate while another group was moved to a 100-feddans banana orchard located in Basioun City, Gharbia Govenorate. In each location, 6 colonies were used to evaluate the numbers of incoming bee/min and pollen foragers/min, stored pollen area $\left(\mathrm{cm}^{2}\right)$, worker sealed brood area $\left(\mathrm{cm}^{2}\right)$, honey yield $(\mathrm{kg})$ and bee population. The remaining three colonies were used to examine queen rearing and royal jelly production.

\section{Nectar secretion and sugar concentration in banana flowers}

In the present study, we focused on female flowers of banana. The number of female flowers per banana plant was recorded during the early morning in the banana orchard located in Basioun City. 9 banana plants were randomly chosen to examine the average number of flowers per feddan (the average numbers of plants per feddan was $2040 \pm 50.99$ and $2050 \pm 50.00$ during 2016 and 2017, respectively). Also, each of 39 stem flowers selected was covered by a plastic bag during the early morning before honeybees visits, and was used for nectar collection twice a week from early August to midOctober. The nectar was collected by a regular medical syringe, and, at the same time, the sugar concentration was evaluated directly in the field using a hand-held refractometer hourly from 6 am to 6 pm from 9 covered flowers and 9 opened flowers, as well (from three different plants). According to Taha and Bayoumi (2006), the expected honey yield per feddan was calculated with the following equation:

\section{Expected honey yield/Feddan

$$
=\frac{\text { Amount of sugar/feddan }}{\text { Sugar concentration in honey }(80 \%)}
$$

In addition, air temperature and relative humidity were recorded hourly from 6 am to $6 \mathrm{pm}$ during the above mention experiment to estimate the relationship between day-time and nectar secretion or sugar concentration.

\section{Activities of honeybee colonies}

The number of honeybee workers visiting each individual banana plant per minute was recorded hourly from 6 am to $6 \mathrm{pm}$. The numbers of forager bees and pollen foragers/colony/minute were also recorded every two hours from 7 am until $5 \mathrm{pm}$. In addition, the area of stored pollen $\left(\mathrm{cm}^{2}\right)$ and worker sealed brood were measured at 12 days interval. Frames were collected to evaluate honey yield by the end of banana blooming season in mid-October.

\section{Queen rearing and royal jelly production}

In the mid-September, six colonies were divided into two equal groups, and queenless rearing colonies were used for queen rearing and royal jelly production. 
Each colony was provided with 15 wax cups, and grafted with 24 hours-old larvae for queen rearing and royal jelly production. After three days, royal jelly was collected and weighted (mg). Repined queen cells were taken to emergence cages until the new queens were emerged, and the queens' weights were also measured.

\section{Statistical analyses}

Data were analyzed using SPSS software (SPSS, 2006). Significant differences were detected using one way analysis of variance (ANOVA). Also, the correlations among the number of honeybees per plant, the amount of nectar secretion (in uncovered flowers) per flower, sugar concentration and relative humidity were examined with Spearman's rank correlation coefficient.

\section{RESULTS}

\section{Nectar secretion (mg) and sugar concentration (\%)}

The data are summarized in Table 1 . The amounts of nectar secretion were about $54.84 \pm 15.21$ and 58.37 $\pm 16.19 \mathrm{mg} /$ flower, and the percentage of sugar concentration was $15.54 \pm 4.31 \%$ and $16.54 \pm 4.58 \%$, during 2016 and 2017 seasons, respectively. Basing on these data and the data on the numbers of banana plants and flowers per plant, it was estimated that a banana orchard of one feddan should produce 29.22 and $31.51 \mathrm{~kg}$ nectar in 2016 and 2017, respectively, which were equivalent to 4.54 and $5.21 \mathrm{~kg}$ sugar. Hence, total honey yields per feddan were estimated as 5.67 and $6.51 \mathrm{~kg}$ during 2016 and 2017 seasons, respectively.

\section{Daytime effect on honeybee activity, nectar secre- tion and sugar concentration}

A large number of honeybees were observed visiting banana flowers during the field experimental periods but honeybee visits were evidently daytime dependent. The average numbers of honeybees per banana plant in relation to daytime observed in 2016 were summarized in Table 2. On uncovered flowers, the highest average of honeybee visits was $11.14 \pm 0.50 /$ min (mean $\pm \mathrm{SE}$ ) at $6 \mathrm{am}$, followed by $10.28 \pm 0.42 / \mathrm{min}$ at $7 \mathrm{am}$. Bee visits decreased gradually to reach zero at $3 \mathrm{pm}$.

Nectar secretion and sugar concentration in uncovered control flowers were also daytime-dependent. The highest nectar secretion and sugar concentration were $63.57 \pm 1.20 \mathrm{mg}$ and $16.92 \pm 0.14 \%$, respectively, which had been recorded at $6 \mathrm{am}$. The both values decreased gradually to reach zero at $3 \mathrm{pm}$. On the other hand, the highest amount of nectar secretion and sugar concentration in covered flowers was $63.35 \pm 1.25 \mathrm{mg}$ and $16.82 \pm$ $0.13 \%$ per flower at $6 \mathrm{am}$, respectively, and the values did not show a marked decrease depending on daytime

Table 1. Nectar secretion and sugar concentration of banana flowers, and expected honey yield during banana blooming period in 2016 and 2017 seasons. Data are shown as mean $\pm \mathrm{SE}$

\begin{tabular}{ccccccccc}
\hline \multirow{2}{*}{ Year } & \multirow{2}{*}{$\begin{array}{c}\text { No. Plants/ } \\
\text { feddan }\end{array}$} & \multicolumn{2}{c}{ No. Flowers } & \multirow{2}{*}{$\begin{array}{c}\text { Nectar (mg)/ } \\
\text { flower }\end{array}$} & $\begin{array}{c}\text { Sugar } \\
\text { concentration } \\
\text { (\%) }\end{array}$ & $\begin{array}{c}\text { Nectar (kg)/ } \\
\text { feddan }\end{array}$ & $\begin{array}{c}\text { Sugar (kg)/ } \\
\text { feddan }\end{array}$ & $\begin{array}{c}\text { Expected } \\
\text { honey yield } \\
\text { (kg)/feddan }\end{array}$ \\
\hline \multirow{2}{*}{2016} & $2040 \pm 50.99$ & $261.2 \pm 11.09$ & 53288 & $54.84 \pm 15.21$ & $15.54 \pm 4.31$ & 29.22 & 4.54 & 5.67 \\
2017 & $2050 \pm 50.00$ & $263.4 \pm 7.52$ & 539970 & $58.37 \pm 16.19$ & $16.54 \pm 4.58$ & 31.51 & 5.21 & 6.51 \\
\hline
\end{tabular}

Table 2. Relationship between honeybee visits, nectar secretion and sugar concentration in banana flowers, and air temperature and relative humidity throughout the day during flowering season in 2016. Data are shown as mean $\pm \mathrm{SE}$

\begin{tabular}{|c|c|c|c|c|c|c|c|}
\hline \multirow[b]{2}{*}{$\begin{array}{l}\text { Hour of the } \\
\text { day }\end{array}$} & \multirow{2}{*}{$\begin{array}{c}\text { The average } \\
\text { number of bee/ } \\
\text { plant/ } \\
\text { min }\end{array}$} & \multicolumn{2}{|c|}{ Uncovered flowers } & \multicolumn{2}{|c|}{ Covered flowers } & \multirow[b]{2}{*}{$\begin{array}{l}\text { Air temperature } \\
{ }^{\circ} \mathrm{C}\end{array}$} & \multirow[b]{2}{*}{$\begin{array}{l}\text { Relative } \\
\text { humidity }\end{array}$} \\
\hline & & $\begin{array}{l}\text { Nectar (mg)/ } \\
\text { flower }\end{array}$ & $\begin{array}{c}\text { Sugar } \\
\text { concentration } \\
(\%)\end{array}$ & $\begin{array}{l}\text { Nectar (mg)/ } \\
\text { flower }\end{array}$ & $\begin{array}{c}\text { Sugar } \\
\text { concentration } \\
(\%)\end{array}$ & & \\
\hline $6 \mathrm{am}$ & $11.14 \pm 0.50$ & $63.57 \pm 1.20$ & $16.92 \pm 0.14$ & $63.35 \pm 1.25$ & $16.82 \pm 0.13$ & $25.50 \pm 0.18$ & $67.85 \pm 7.10$ \\
\hline $7 \mathrm{am}$ & $0.42 \pm 10.28$ & $57.33 \pm 1.10$ & $16.00 \pm 0.28$ & $62.85 \pm 1.16$ & $16.57 \pm 0.14$ & $26.57 \pm 0.29$ & $64.28 \pm 7.55$ \\
\hline $8 \mathrm{am}$ & $6.28 \pm 0.42$ & $47.58 \pm 1.56$ & $15.66 \pm 0.07$ & $57.57 \pm 1.16$ & $16.39 \pm 0.21$ & $28.14 \pm 0.50$ & $59.00 \pm 7.70$ \\
\hline $9 \mathrm{am}$ & $3.0 \pm 0.30$ & $39.41 \pm 2.66$ & $14.25 \pm 0.38$ & $56.35 \pm 1.27$ & $15.89 \pm 0.29$ & $29.71 \pm 0.42$ & $48.42 \pm 5.78$ \\
\hline $10 \mathrm{am}$ & $2.28 \pm 0.35$ & $19.91 \pm 1.36$ & $12.00 \pm 0.57$ & $56.14 \pm 0.68$ & $15.85 \pm 0.32$ & $30.71 \pm 0.28$ & $43.71 \pm 4.72$ \\
\hline $11 \mathrm{am}$ & $1.57 \pm 0.29$ & $19.58 \pm 1.30$ & $11.16 \pm 0.83$ & $54.57 \pm 0.95$ & $15.78 \pm 0.26$ & $32.71 \pm 0.52$ & $37.57 \pm 4.42$ \\
\hline $12 \mathrm{am}$ & $1.37 \pm 0.25$ & $16.08 \pm 0.78$ & $10.16 \pm 0.55$ & $52.92 \pm 0.77$ & $15.60 \pm 0.24$ & $33.42 \pm 0.48$ & $34.57 \pm 4.25$ \\
\hline $1 \mathrm{pm}$ & $1.28 \pm 0.18$ & $13.91 \pm 0.81$ & $8.83 \pm 0.66$ & $52.00 \pm 1.00$ & $15.42 \pm 0.19$ & $34.14 \pm 0.59$ & $31.00 \pm 3.66$ \\
\hline $2 \mathrm{pm}$ & $0.42 \pm 0.20$ & $10.91 \pm 0.50$ & $8.58 \pm 0.39$ & $51.71 \pm 0.89$ & $15.37 \pm 0.13$ & $34.71 \pm 0.42$ & $30.71 \pm 3.11$ \\
\hline $3 \mathrm{pm}$ & 0 & 0 & 0 & $51.64 \pm 0.64$ & $15.13 \pm 0.27$ & $33.57 \pm 0.36$ & $31.14 \pm 4.03$ \\
\hline $4 \mathrm{pm}$ & 0 & 0 & 0 & $51.57 \pm 0.65$ & $14.57 \pm 0.20$ & $33.42 \pm 0.52$ & $32.57 \pm 4.10$ \\
\hline $5 \mathrm{pm}$ & 0 & 0 & 0 & $51.35 \pm 0.71$ & $14.38 \pm 0.16$ & $32.71 \pm 0.53$ & $39.14 \pm 4.92$ \\
\hline $6 \mathrm{pm}$ & 0 & 0 & 0 & $50.92 \pm 0.67$ & $14.25 \pm 0.15$ & $31.85 \pm 0.50$ & $40.71 \pm 4.77$ \\
\hline
\end{tabular}


(Table 2).

The results of the field experiments conducted in 2017 had almost the same trend as those in 2016, as shown in Table 3. The highest mean number of bee visits per plant, the value of which was $11.28 \pm 0.43$, was recorded in the earliest daytime, i.e., at $6 \mathrm{am}$, and the mean bee visits gradually declined to reach zero at $3 \mathrm{pm}$. The highest nectar secretion and sugar concentration $(66.50 \pm 0.60 \mathrm{mg}$ and $18.35 \pm 0.16 \%$ per flower, respectively) were again recorded at $6 \mathrm{am}$, and both values declined to zero by $3 \mathrm{pm}$. The highest nectar secretion and sugar concentration were also recorded in covered flowers $(65.92 \pm 0.71 \mathrm{mg}$ and $18.07 \pm 0.13 \%$ per flower, respectively) at $6.00 \mathrm{am}$, but the vaues again did not change markedly during the daytime, the lowest values $(55.00 \pm 1.00 \mathrm{mg}$ and $15.59 \pm 0.15$

Next, the effects of environmental factors on nectar production and honeybee attraction were examined by checking correlations between them. In 2016, air humidity was found positively correlated to the average number of bee visits per plant per day, nectar secretion and sugar concentration in uncovered flowers in regards to relative air humidity (Pearson correlation $=0.67,0.66$, and 0.67 respectively at $p \leq 0.05$ ). The number of bees visiting per plant negatively correlated with air temperature (Pearson correlation $=-0.67$ at $p \leq 0.05$ ). The same trend was noticed during 2017 season. There were a positive correlation between air humidity and bee numbers, or nectar secretion or sugar concentration, in uncovered flowers (Pearson correlation=0.97, 0.89, and 0.94 respectively at $p \leq 0.01$ ), whereas the correlation between bee visits and air temperature was negative (Pearson correlation $=-0.91$ at $P \leq 0.01$ ).

\section{Influence of banana flowers on flying and biologi- cal activities of honeybee colonies}

The data were summarized in Table 4. Striking effects of banana flowers was noticed on flying and biological activities of bee colonies when they were compared between the two localities in both seasons. One way ANOVA detected signficant differences in the following parameters; the numbers of incoming bee/min $\left(\mathrm{F}_{1,12}=0.20, P \leq 0.01\right.$ and $\mathrm{F}_{1,12}=0.95, P \leq 0.01$ in 2016 and 2017, respectively), the numbers of pollen foragers/min $\left(\mathrm{F}_{1,8}=0.61, P \leq 0.01\right.$ and $\mathrm{F}_{1,12}=0.85, P \leq 0.01$ in 2016 and 2017 , respectievly), stored pollen area $\left(\mathrm{F}_{1,8}=0.002, P \leq\right.$ 0.01 and $\mathrm{F}_{1,8}=0.31, P \leq 0.01$ in 2016 and 2017 , respectively), worker brood rearing area $\left(\mathrm{F}_{1,8}=0.50, P \leq 0.01\right.$ and $\mathrm{F}_{1,8}=0.63, P \leq 0.01$ in 2016 and 2017), honey yield/ colony (kg) $\left(\mathrm{F}_{1,8}=0.01, P \leq 0.01\right.$ and $\left.\mathrm{F}_{1,8}=0.01, P \leq 0.01\right)$, bee population $\left(\mathrm{F}_{1,8}=0.33, P \leq 0.01\right.$ and $\mathrm{F}_{1,8}=0.33, P \leq$ 0.01 in 2016 and 2017, respectively) and the weight of virgin queens $\left(\mathrm{F}_{1,12}=0.08, P \leq 0.01\right.$ and $\mathrm{F}_{1,12}=0.23, P \leq$ 0.01). Additionally, the percentage of accepted larvae were higher in Basioun, where banana flowers were available, than those in Qulin (Table 4). While there was no statistical difference in the royal jelly yield in the year of $2016\left(\mathrm{~F}_{1,10}=0.53, P>0.05\right)$, a distinct significant difference was detected in $2017\left(\mathrm{~F}_{1,10}=0.88, P \leq 0.01\right)$. All of those parameters indicated that honeybee activity was high in the location with banana flowers.

\section{DISCUSSION}

In the present study, we have focused on banana flowers that can supply nectar and pollen for honeybees during times of dearth when other blooming plants are unavailable or restricted. In the Mediterranean region, including Egypt, the dearth period for apiculture typically occurs between late summer to winter seasons. Flowers of crop plants can provide good resources for honeybees although concern may be a potential for pesticide or agro-chemical exposure. Banana can be one of the best selections among crop plants because pesticides

Table 3. Relationship between honeybee visits, nectar secretion and sugar concentration in banana flowers, and air temperature and relative humidity throughout the day during flowering season in 2017. Data are shown as mean $\pm \mathrm{SE}$

\begin{tabular}{|c|c|c|c|c|c|c|c|}
\hline \multirow[b]{2}{*}{$\begin{array}{c}\text { Hour of the } \\
\text { day }\end{array}$} & \multirow{2}{*}{$\begin{array}{c}\text { The average } \\
\text { number of bee/ } \\
\text { plant/ } \\
\text { min }\end{array}$} & \multicolumn{2}{|c|}{ Uncovered flowers } & \multicolumn{2}{|c|}{ Covered flowers } & \multirow[b]{2}{*}{$\begin{array}{c}\text { Air } \\
\text { temperature } \\
{ }^{\circ} \mathrm{C}\end{array}$} & \multirow[b]{2}{*}{$\begin{array}{l}\text { Relative } \\
\text { humidity }\end{array}$} \\
\hline & & $\begin{array}{l}\text { Nectar (mg)/ } \\
\text { flower }\end{array}$ & $\begin{array}{c}\text { Sugar } \\
\text { concentration } \\
(\%)\end{array}$ & $\begin{array}{l}\text { Nectar (mg)/ } \\
\text { flower }\end{array}$ & $\begin{array}{c}\text { Sugar } \\
\text { concentration } \\
(\%)\end{array}$ & & \\
\hline $6 \mathrm{am}$ & $11.28 \pm 0.43$ & $66.50 \pm 0.60$ & $18.35 \pm 0.16$ & $65.92 \pm 0.71$ & $18.07 \pm 0.13$ & $24.28 \pm 0.42$ & $77.71 \pm 1.84$ \\
\hline $7 \mathrm{am}$ & $10.39 \pm 0.29$ & $59.32 \pm 1.02$ & $17.16 \pm 0.21$ & $65.42 \pm 0.94$ & $17.70 \pm 0.09$ & $25.14 \pm 0.34$ & $72.85 \pm 1.77$ \\
\hline $8 \mathrm{am}$ & $6.22 \pm 0.25$ & $48.82 \pm 1.46$ & $16.66 \pm 0.24$ & $61.41 \pm 0.71$ & $17.67 \pm 0.21$ & $26.42 \pm 0.61$ & $66.71 \pm 2.17$ \\
\hline $9 \mathrm{am}$ & $3.15 \pm 0.09$ & $38.16 \pm 3.12$ & $15.33 \pm 0.24$ & $60.14 \pm 1.14$ & $16.65 \pm 0.15$ & $28.00 \pm 0.53$ & $58.85 \pm 2.93$ \\
\hline $10 \mathrm{am}$ & $2.35 \pm 0.18$ & $21.75 \pm 1.15$ & $13.58 \pm 0.58$ & $59.07 \pm .078$ & $16.60 \pm 0.09$ & $29.42 \pm 0.57$ & $48.85 \pm 3.61$ \\
\hline $11 \mathrm{am}$ & $1.49 \pm 0.16$ & $20.25 \pm 1.78$ & $12.00 \pm 0.53$ & $59.00 \pm 1.34$ & $16.32 \pm 0.17$ & $30.00 \pm 0.65$ & $40.71 \pm 3.57$ \\
\hline $12 \mathrm{am}$ & $1.42 \pm 0.15$ & $16.75 \pm 0.91$ & $10.50 \pm 0.57$ & $56.57 \pm 1.13$ & $16.40 \pm 0.16$ & $32.00 \pm 0.80$ & $36.85 \pm 4.31$ \\
\hline $1 \mathrm{pm}$ & $0.94 \pm 0.09$ & $14.50 \pm 1.07$ & $9.58 \pm 0.67$ & $55.78 \pm 0.76$ & $16.30 \pm 0.13$ & $33.00 \pm 0.81$ & $33.87 \pm 4.48$ \\
\hline $2 \mathrm{pm}$ & $0.57 \pm 0.20$ & $11.83 \pm 1.00$ & $9.00 \pm 0.46$ & $55.28 \pm 0.35$ & $16.04 \pm 0.15$ & $34.14 \pm .082$ & $33.57 \pm 4.17$ \\
\hline $3 \mathrm{pm}$ & 0 & 0 & 0 & $55.14 \pm 0.50$ & $16.07 \pm 0.15$ & $34.28 \pm 0.82$ & $31.00 \pm 4.04$ \\
\hline $4 \mathrm{pm}$ & 0 & 0 & 0 & $55.07 \pm 1.01$ & $15.94 \pm 0.16$ & $33.70 \pm 0.77$ & $27.42 \pm 3.02$ \\
\hline $5 \mathrm{pm}$ & 0 & 0 & 0 & $55.07 \pm 1.03$ & $15.69 \pm 0.15$ & $33.57 \pm 0.68$ & $31.00 \pm 3.94$ \\
\hline $6 \mathrm{pm}$ & 0 & 0 & 0 & $55.00 \pm 1.00$ & $15.59 \pm 0.15$ & $31.57 \pm 0.92$ & $27.85 \pm 2.30$ \\
\hline
\end{tabular}


Table 4. Influence of banana flowers on flying and biological activities of honeybee colonies in two different locations during 2016 and 2017 seasons. Data are shown as mean $\pm \mathrm{SE}$

\begin{tabular}{|c|c|c|c|c|c|}
\hline & \multirow{2}{*}{ Parameters } & \multicolumn{2}{|c|}{2016} & \multicolumn{2}{|c|}{2017} \\
\hline & & Qulin location & Banana location & Qulin location & Banana location \\
\hline \multirow{2}{*}{$\begin{array}{l}\text { Flight } \\
\text { activities }\end{array}$} & No. incoming bee/min & $20.94 \pm 0.55$ & $30.60 \pm 0.60$ & $21.24 \pm 0.43$ & $31.86 \pm 0.44$ \\
\hline & No. pollen foragers/min & $6.04 \pm 0.35$ & $9.90 \pm 0.40$ & $6.33 \pm 0.21$ & $10.50 \pm 0.26$ \\
\hline \multirow{7}{*}{$\begin{array}{l}\text { Biological } \\
\text { activities }\end{array}$} & Stored pollen area $\left(\mathrm{cm}^{2}\right) /$ colony & $121.38 \pm 1.14$ & $155.46 \pm 4.23$ & $124.44 \pm 1.24$ & $172.12 \pm 2.04$ \\
\hline & Worker sealed brood area $\left(\mathrm{cm}^{2}\right) /$ colony & $1076.50 \pm 23.53$ & $1223.46 \pm 15.76$ & $1201.65 \pm 23.03$ & $1419.49 \pm 19.88$ \\
\hline & Honey yield (kg)/colony & 0.00 & $2.53 \pm 0.08$ & 0.00 & $2.86 \pm 0.12^{* * *}$ \\
\hline & No. honeybee /colony & $8080 \pm 177.20$ & $11600 \pm 242.89$ & $9120 \pm 146.28$ & $13280 \pm 208.32$ \\
\hline & The weight of virgin queens (mg) & $155.00 \pm 154$ & $160.00 \pm 2.02$ & $157.83 \pm 1.41$ & $167.16 \pm 1.37$ \\
\hline & The weight of royal jelly (mg)/cup & $110.48 \pm 0.85$ & $112.00 \pm 1.15$ & $108.33 \pm 1.02$ & $115.61 \pm 1.16$ \\
\hline & The larvae accepted percentage & 63 & 70 & 60 & 76 \\
\hline
\end{tabular}

are not used and because it is known that the flowers are nectar rich.

Banana inflorscence is composed of hundreds of complete (hermaphrodite) flowers. The majority of flowers start from the base of the inflorence, which are called 'female flowers' since they have long ovary and later on form a parthenocarpic banana fruit (Simmonds, 1959, 1962). Flowers at the top of the inflorence are called 'male flowers' since they have very small ovary and do not form fruits. Although both types of flowers produce nectar and pollens, we focused on female flowers because they produce more nectar and sugar (Simmonds, 1959; Liu et al., 2002), meaning that female flowers are the main source of nectar for honeybees visiting banana flowers, and Apidae, including honeybees, is among the visitor insects (e.g., Free, 1993; Rutikanga et al., 2016).

In the present study, we have shown that a large number of honeybees visit flowers of banana (Tables 2 and 3). A manipulation experiment of banana flowers has given evidence that the amount of nectar decreases quickly as hours of the day increase while covered flowers keep a full volume of nectar (Table 2 and 3). Because honeybees are the majory flower visitors in our study fields, the reduction of nectar should be mostly due to honeybees. In fact, honey yield in that locality was markedly high when compared with another locality where banana flowers were not available (Table 4). These results indicate that banana flowers are a good source of nectar for honeybees.

Further, our study suggests that banana flowers are sufficient to sustain bee colonies during the dearth period. In Qulin, where no banana was present, honey yield was zero for two years and colony size was much smaller than in Basioun where banana floweres were available; bee colonies in Basioun remained strong during the dearth period (Table 4). In addition, the number of pollen foragers was greater, and stored pollens were also larger, in Basioun, suggesting a usefulness of banana flowers as a pollen source.

Some previous studies revealed a usefulness of alternative nectar and/or pollen sources during dearth peri- ods; however, these sources may not always be enough because the availability depends largely on locations. Taha and Bayoumi (2006) found that Citrullus lanatus var colothynthoides L. could produce $18.98 \mathrm{~kg}$ floral nectar/feddan that contained $3.52 \mathrm{~kg}$ sugar, which in turn produced $4.40 \mathrm{~kg}$ honey/feddan. Also, Taha et al. (2006) showed that one feddan of Luffa aegyptiaca Mill. could produce $35.44 \mathrm{~kg}$ of nectar contained $6.84 \mathrm{~kg}$ sugar that produce $8.55 \mathrm{~kg}$ honey/feddan. The mean honey production of Ziziphus nummularia was about $2.998 \mathrm{~kg} /$ tree and $749.475 \mathrm{~kg} / \mathrm{ha}$ during the main bloom period (Alqarni, 2015) while sparse plantation of Eucalyptus eryihrocom (280 trees/ha) can produce $250 \mathrm{~kg}$ honey per ha (Lupo and Eisikowiteh, 1990). The present study have revealed that female banana flowers can produce around $30 \mathrm{~kg} /$ feddan nectar, which may lead to about $5.7-6.5 \mathrm{~kg}$ honey production (Table 1). This means that banana flowers have a moderate amount of nectar and are sufficient for economizing the feeding cost, conserving and building-up the honey bee colonies when nectar sources are scarce.

Our field study has demonstrated positive correlations between the average bee visit per plant per day and nectar quantity or sugar concentration in uncovered flowers (Table 2 and 3). Similar results have been reported previously (e.g., Mallinger and Prasifka, 2017), and such relationships should arise because honeybees can assess nectar rewards during flower visits. Banana flowers have a high amount of nectar with a high sugar concentration at $6 \mathrm{am}$, but additional nectar production seems not to occur because it does not increase on covered flowers. In contrast, the amoung of nectar declines to zero until $3 \mathrm{pm}$ on uncovered, bee-visiting flowers (Table 2 and 3). Similar results were reported for the flowering plants (Abo-Lila and Ghoneimy, 1998; AboLila and Sadek, 1998; Corbet, 2003; Karp et al., 2004); the nectar secretion generally increased during the early morning, peaked around mid-day, followed by a decline until reached zero though different plant species have different time of nectar secretion peak (Adgaba et al., 2017). In any case, the most vital factors that attract honeybees are the amount of nectar and its sugar con- 
centration (Abrol, 1990; Free, 1993; Alqarni, 2015). Frequent visits by honeybees observed on banana flowers thus indicate that banana is an attractive source of nectar for honeybees in the dearth period.

In our study, we have evaluated the activity and productivity of honeybees to give the evidence for a usefulness of banana flowers. The present results have indicated increases in the numbers of foragers/min and the amount of pollen/foraging/min when banana flowers are available. The increased levels of activity in fact resulted in greater levels of stored pollen, worker brood rearing, honey yield/colony, bee population, weight of virgin queens, royal jelly yield and percentage of larvae accepted. We thus suggest that moving bee hives to an area where banana flowers are available will help honeybee colonies to keep their strength and productivity. The usefulness of moving the apiaries for beekeeping in Egypt was also confirmed by Helal et al. (2003).

Because honeybees rely on nectar and pollens, the presence of good nectar and pollen plants is crucial for beekeeping. Because the majority of plants are in bloom for a short period, moving the colonies from one place to another where a large abundance of floral resources is available can be an effective practice, in particular, during times of dearth. This is what we have shown in the present study; moving and placing bee hives in or near banana orchards can help honeybees maintaining their colonies and honey stores. Protecting and maintaining the flowering source of nectar can also be a good practice. If necessary, creating floral areas may be an option. In these cases, maintaining the floral resource should be important; for example, pest management of Chinese milk vetch with an environmentally friendly practice can be a good practice to preserve the nectar source (Shobu et al., 2005; Takagi et al., 2005).

Thus, we conclude that it is very important to move honeybee colonies (apiaries) into banana locations, especially during the dearth period (August -October) to maintain colonies' growth and strength so that it may improve honey yield and decrease the cost of artificial feeding.

\section{AUTHOR CONTRIBUTIONS}

M. B. Shawer, O. M. Rakha, E. M. Elnabawy and A. A. Elashmawy designed and achieved the field study and wrote the initial draft of the manuscript. T. Ueno discussed the results of this work and polished up the manuscript.

\section{ACKNOWLEDGMENTS}

We would like to acknowledge all staff members of Economic Entomology Department, Faculty of Agriculture, Kafrelsheikh University, for their great help during the field investigation. Thanks are due to Dr. Shamel M. Alam-Eldein, Department of Pomology, Faculty of Agriculture, Kafrelsheikh University, for his valuable comments and advice.

\section{REFERENCES}

Abo-Lila, S. M. and A. A. Sadek 1998 Influence of insect pollinators concerning honey bees on seed formation, quantity and quality of seed and oil yield of Carum carvi L. and Pimpinella anisum L. in Giza region. J. Agric. Sci. Mansoura Univ., 23 : 3771-3784

Abo-Lila, S. M. and H. A. Ghoniemy 1998 Evaluation of the role of borage Borago officinalis L. as a source of pollen under Dokki conditions, with observations on honey bees as pollinators. $J$. Agric. Sci. Mansoura Univ., 23: 3401-3409

Abrol, D. P. 2004 Abelia grandiflora. Bee World, 85: 12

Abrol, D. P. 1990 Energetics of nectar production in some apple cultivars as a predictor of floral choice by honeybees. Trop. Ecol., 31: 116-122

Adgaba, N., A. Al-Ghamdi, Y. Tadesse, A. Getachew, A. M. Awad, M. J. Ansari and A. S. Alqarni 2017 Nectar secretion dynamics and honey production potentials of some major honey plants in Saudi Arabia. Saudi J. Biol. Sci., 24: 180-191

Al-Busaidi, K. T. S. 2013 Banana domestication on the Arabian Peninsula: A review of their domestication history. J. Hort. Forest., 5: 194-203

Alqarni, A. S. 2015 Honeybee foraging, nectar secretion, and honey potential of wild jujube trees, Ziziphus nummularia. Neotrop. Entomol., 44: 232-241

Atwal, A. S. 2000 Essentials of Beekeeping and Pollination, Edn 1, Kalyani Publishers, New Delhi

Corbet, S. A. 2003 Nectar sugar content: estimating standing crop and secretion rate in the field. Apidologie, 34: 1-10

Eisikowitch, D. and Y. Masad 1980 Nectar-yielding plants during the dearth season in Israel. Bee World, 61: 11-18

Endress, P. K. 1994. Diversity and Evolutionary Biology of Tropical Flowers. Cambridge University Press, Cambridge, England

FAO. 2016 Production statistics. Available at: http://faostat3.fao. org/browse/Q/QC/E. Garrity, G.M. (2005) "Genus Xanthomonas." In: Bergey's Manual of Systematic Bacteriology; the Proteobacteria, Vol. 2, 2nd edn., (Brenner D.J., Kreig, N. R. and Staley, J. T., eds), p. 87. New York: Springer-Verlag

Free, J. F. 1993 Insect Pollination of Crops. Academic Press, San Diego.

Helal, R. M., T. N. El-Dakhakhni, M. B. Shawer and E. A. Taha 2003 Effect of moving the apiaries on activity of honey bee colonies. 2- Flight activity, gathering of nectar and sugar concentration contents and honey. J. Agric. Res. Tanta Univ., 29: 268-282

Ho, T. T. G. and T. Ueno 2011 The effects of honey as a dietary supplement on the survivorship and nutrition-storing capacity of Hemiptarsenus varicomis (Hymenoptera: Eulophidae), a parasitoid of Liriomyza (Diptera: Agromyzidae) leafminers. Int. J. Trop. Insect Sci., 78: 78-84

Itino, T., M. Kato and M. Hotta 1991 Pollination ecology of the two wild bananas, Musa acuminata subsp. halabanensis and $M$. salaccens: Chiropterophily and ornithophdy. Biotropica, 23: $151-158$

Karamura, E. B., F. L. Turyagyenda, W. Tinzaara, G. Blomme, F. Ssekiwoko, S. Eden-Green, A. Molina and R. Markmham 2008 Xanthomanas wilt of banana in East and Central Africa. Diagnostic and Management Guide. Bioversity International. Rome, Italy INIBAP ISBN, 978-982

Karp, K., M. Mänd, M. Starast and T. Paal 2004 Nectar production of Rubus arcticus. Agron. Res., 2: 57-61

Liu, A. Z., D. Z. Li, H. Wang and W. J. Kress 2002 Ornithophilous and Chiropterophilous pollination in Musa itinerans (Musaceae), a pioneer species in tropical rain forests of Yunnan, southwestern China. Biotropica, 34: 254-260

Lupo, A. and D. Eisikowitch 1990 Eucalyptus erythrocoris; a source of nectar and pollen for honey bees in Israel. Apidologie, 21: $25-33$

Mallinger, R. E. and J. R. Prasifka 2017 Bee visitation rates to cultivated sunflowers increase with the amount and accessibility of nectar sugars. J. Appl. Entomol., 141: 561-573

Mohanna, N. E. 1989 An important source of nectar and pollen 
during the dearth period in Egypt. Alex. J. Agric. Res., 34: 173182

Nicolson S. W. and M. Nepi 2005 Nectar volume and concentration in Aloe castarea flowers. Int. J. Plant Sci., 166: 227-233

Sharaf, A. A. 1996 Studies on honey bees Apis mellifera L, in ELBeheira Governorate. M. Sc. Thesis, Fac. Agric. Alex. Univ., 88pp

Shawer, M. B. 1987 Major pollen sources in Kafr El-Sheikh, Egypt and the effect of pollen supply on brood area and honey yield. $J$. Apic. Res., 26: $43-46$

Shawer, M. B., A. I. El-Zawily, S. M. Metwally and M. M. Ghazy 1981 The efficiency of honey bees as pollinators of summer squash (Cucurbita pepo L.). J. Agric. Res. Tanta Univ., 7: 225-238

Shawer, M. B., Z. Shenishen and N. M. El-Dakhakhni 1986 Effect of colony strength on flight activity and productivity of honey bee colonies. Bull. Ent. Soc. Egypt, 66: 65-73

Shoubu M., M. Okumura, A. Shiraishi, H. Kimura, M. Takagi and T. Ueno 2005 Establishment of Bathyplectes anurus (Hymenoptera: Ichneumonidae), a larval parasitoid of the alfalfa weevil, Hypera postica (Coleoptera: Curculionidae) in Japan. Biol. Cont., 34: 144-151
Simmonds, N. W. 1959 Bananas. Longmans, Green \& Co., London, UK

Simmonds, N. W. 1962 The Evolution of Bananas. Longmans, Green and Co. Ltd., London, UK

SPSS 2006 SPSS15.0 for Windows. SPSS Inc. Chicago, IL

Suryanarayana, M. C., G. M. Rao and T. S. Singh 1990 Coconut palm- a pollen and nectar source to honey bees. Indian Bee J., 52: $41-43$

Taha, E. A. and Y. A. Bayoumi 2006 The efficiency of honey bee (Apis mellifera L.) as pollinator of seed watermelon (Citrullus lanatus var. colothynthoides L: Cucurbitaceae). J. Biol. Chem. Environ. Sci., 1: 899-912

Taha, E. A., M. E. Nour and M. B. Shawer 2006 Loofah (Luffa aegyptiaca Mill., Cucurbitaceae); a source of nectar and pollen for honey bee Apis mellifera L. (Hymenoptera: Apidae) in Egypt. Bull. Ent. Soc. Egypt, 83: 337-345

Takagi M., M. Shoubu, M. Okumura, A. Shiraishi, H. Kimura and T. Ueno 2005 Classical biological control of the alfalfa weevil in Japan. Int. Symp. Bio. Cont. Arthropods, 2: 14-18 